\title{
Quality of the Urban Environment as Perceived by Residents of Slow and Fast Growth Cities
}

by Raymond F. Currie \& Charlene Thacker

1985

The Institute of Urban Studies

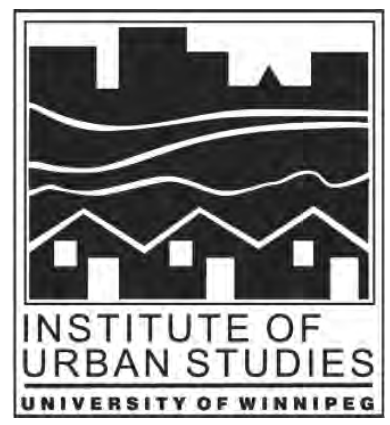



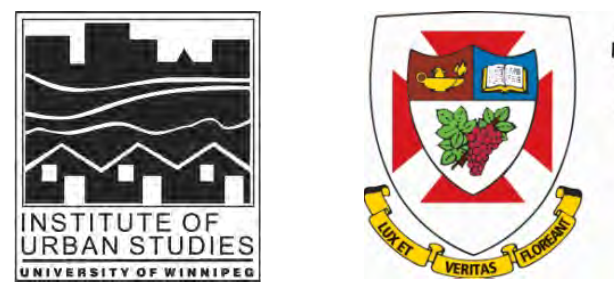

\section{THE UNIVERSITY OF WINN I PEG}

FOR INFORMATION:

The Institute of Urban Studies

The University of Winnipeg

599 Portage Avenue, Winnipeg

phone: 204.982.1140

fax: 204.943.4695

general email: ius@uwinnipeg.ca

Mailing Address:

The Institute of Urban Studies

The University of Winnipeg

515 Portage Avenue

Winnipeg, Manitoba, R3B 2E9

\section{Quality of the Urban Environment as Perceived by Residents of Slow and Fast Growth CiTiES \\ Published 1985 by the Institute of Urban Studies, University of Winnipeg (C) THE INSTITUTE OF URBAN STUDIES}

Note: The cover page and this information page are new replacements, 2016.

The Institute of Urban Studies is an independent research arm of the University of Winnipeg. Since 1969, the IUS has been both an academic and an applied research centre, committed to examining urban development issues in a broad, non-partisan manner. The Institute examines inner city, environmental, Aboriginal and community development issues. In addition to its ongoing involvement in research, IUS brings in visiting scholars, hosts workshops, seminars and conferences, and acts in partnership with other organizations in the community to effect positive change. 
OUALITY OF THE UFEAN ENUIFONHEHT AS FERCEIVED BY FESTDENTS OF SLDW AND FAST GFOWTH CITIES

Fiaymond F. Currie University of Manitoba

Charlene Thect:er University of Winripeg

Presented at the Canadian Urban Studies Conference, Winnipeg, Manitoba, August, 1985. 
Quality of Urban Environment as Ferceived by

Fiesidents of Slow and Fast Growth Cities

Growth of an urban population is a highiy complex reality. Increased population, rew business both commercial and industrial, new homes and apartments are all catalysts that feed upon each other: These are assaciated with new modes of transportation as well as new transportation links. The consequences can be varied. Fopuletion growth, or 1 act: thereor, is perceived to be a benchmart: of economic health, so the investment climate is affected. On the other hand, the ability to provide services depends on the tax base. For fast growth cities, new tax revenues al low for new services. However, installation of new physical services can cause congestion, and adequate social services can lag behind the reeds of the newly arrived migrants, as well as those of the settled residents. Slow growth cities face the opposite problem of trying to match the often highly expanded services of their neighbouring cities without the expanding tax base to da so. Yet they do not face the fast $f i x$ approach to urban problems that can inhibit long term, highly efficient and effective planning.

While conditions in fast and slow growth cities obvicusly differ, do residents perceive the quality of the urban environment differently? We will address this issue by comparing Winripeg and 
Edmonton, two cities ir Western Canada with dramatically different growth rates.

We shall tegin with a brief historical review in order to highlight the differences in the growth patterns of the two cities, and then present current socio-demagraphic characteristics. After reviewing the objective measures of growth and painting out the mare visible signs of change or ron-change, we shali then look at the subjective evaluations provided by the residents of the cities in 1981 Surveys, addressing the following questions. I) Do the residents of the two cities have significantly different evaluations of the growth rate of their cities? We would expect this to be the case, given the objective data which we shall present. 2) With the measures at our disposal, how much of the variance in satisfaction with the city can we explair in each of the two cities? 3 Do the same variables and/ar cluster of yariables account for satisfaction in each of the cities? 4) Finally, are the perceptions and assessments of growth in each of the cities significant factors in the levels of satisfaction achieved by residents in each of the cities?

\section{Historical Development}

Winnipeg and Edmanton were cities of fairly equal size in 1981 , both wj.th a relatively brief history of development cabout 
100 years?. However, the growth of the cities has rot been similar. Winripeg had a dramatic expensjon early in the certury whj.h has since slowed to a crawl. Edmonton's atcelerated development began ir the $1950^{\prime}$ s and reached its peat iritie ear 1 y $1980^{\circ}$.

Winripeg's mast dramatic expansion accurred between 19 ad and 1914 when it grew by over ZOb percent (Table 1). As the first eity or the Frairies it consolidated its position early as the chief goverrmental, firancial, commercial and cultural certre of the region (Nader,1976:273). With anly bo miles separecirg the United States border from the lower tip of Lafe Winnipeg, all traffic in Canada east and west filtered through. This included the grain trade as well as wholesale goods. With the development of manufacturing in the city, the econcmic base expanded considerabIy, and the relative Etability of the aree over the years can be attributed to a large extent to this factor. The opening of the Fanama canal in 1914, the dismanteling of preferential freight rates the city enjoyed, and the immigration to other centres on the Frairies, all led to a relative declire of winnipeg and the rise of Vancouver and other Frairie cities. It is a fate that that has often been commented upan (Nader, 1976, frtibise, I977). One image of the city might be that of an aristocrat whose power and forture was eroded with unreascrable speed by the nouveau riche of the region.

Ore the successful challengers to winnipeg s dominant role in 
the West was Edmonton. Its rise to prominence occurred above all following the discovery of oil in the Leduc area in 1947. This ratural resource became the major catalyst for the city's growth, far overshadowing its other advantages as frovincial capital, gateway to the North and uriversity centre.

Edmonton is now the largest prairie metropolitan centre. having surpassed Winnipeg in 1979. In the S0 year period from I. 51 to 1981 the city grew from 195,547 to 657,057 . This was a growth of 239 percent. In the same period, Winnipeg grew from 357,225 to 584,842, a 64 perterit increase. In the decade that ended in 1981 , the year of the survey reported in this paper, Winnipeg grew by only 8.2 percent (44,5s0), while Edmonton grem by 32.6 percerit (161, J55). The minimal growth that did occur in Winnipeg can be accounted for by the net gain of births over deaths. During the ten year period, the out-migration always exceeded the in-migration to winnipeg. In 1779, the net out-migration was 15,457, the highest in twenty years. Edmonton, on the contrary experienced one of the highest net in-migration rates in Cenada in this pericd. While wel 1-educated households tended to be among the mejor cut-migrants from Winnipeg, the in-migrents were often less educated young people, lacking marletable slid.ls. Alberta, and particularly the cities of Calgary and Edmonton, were a major destination of the Manitoba migrants. Eetween 1975 and 1980 Manitoba lost 21,000 persons to Alberta and 13 , wou to B.C. Ghe third of those migrants were between 15 and 24 yeare of ege. Among thase over 25 , one half 
had Ecme post-secondary educetion or higher lstatistice camadan $1992)$.

Until the recent major recession jn Canada, the economy of Manitoba was not strong enough to compete with that of its neighbours. As a relatively low wage, low income frovince, any major growth of the national economy tended to mean that the econamies of ather Fravinces impraved still more than Manitoba's. Therefore, precisely in expanding eccromic times Manitota. experienced net out-migration. Foor economic times tended to slow down the out-migration. This econamic climate has been the subject of a great deal of attention in the media, and the campaigns of political parties often revolve around it. The paint deserves attention because of its potential impact on perceptions and assessments of cities by residerts:

At the time of our research, Manitoba was in the last year of a Fragressive Conservative gavernment (october 1977-November 1981) which was sandwiched between terms of office by the NDF. Alberta was to continue its long standing Conservative government for the forseeable future. The age structure of the two cities was slightly different. While Edmonton had a higher preponderance of both yourg families with children and particularly a higher percentage of 19-24 year old males, Winnipeg had a higher proportion of seniars. Winnipeg had a higher proportion of females (sex ratio of .9.) while Edmontan had more men (1. 02$)$. The cities had ir cammar a 
Eimilar and very high index of ethnic diversity 6.77 and. 75 ; cumpared to other Eities in Canada (Ferspectives Canada 111 , 1980:192). The fercentage with a University education was very similar (19.8\% in winnipeg: $21.1 \%$ in Edmonton).

fimong the types of employment of individuals in the two cities whj.h were summarized in the 1981 census bulletins only two stand out as different. While Winnipeg reported a higher level of involvement in manufacturing $(17.1 \%$ compared to $11.1 \%$, Edmontan reported a much stronger canstruction industry ( $10.7 \%$ compared to 4. $8 \%$ ). While only $3.9 \%$ of Edmontanians were directly invalved in primary industries, clearly it was the gas and oil industry that gave Edmortor its economic boam. The average family income in Edmonton was \$1, 978. compared to Canade, 1981c). Clearly, the economic situation of the two cities was quite different at the beginning of the $1990 \cdot s$.

\section{Visible Signs of Growth or Nan-arcuth}

A dramatic urban growth rate is a highly visible phenomenon. So alson stagnation or decline does not escape public scrutiny. Fossibly the mast obvious indicator of city growth is the construltion boom associated with it. In the late 1970 s cranes 
dominated the shyline of Edmonton, and cement trbchs competed with comruters for space on the downtown streets. New suburbs also sprouted up. Ehart 1 shows the value af building permits issued in Winnnipeg and Edmonton over a ten year period. While the value of permits in the two cities was not far apart in 1971 , by 1980 the value differed by over ore billion dollars a year. cstatistics Carada, 1981 a Canada Year Eoot, 1978-79:615)

Winnipeg reached its peat: of building permits in 1778. Ironically, the declire that foliowed can be accounted for by the high out-migration of precisely those young hausehold units that would be libely ticme tuyers. They were leaving at a time when constructicn in winnipeg was picking up. Thé consequence was a decline in residential tuilding that was so sharp that even an increase in commercial Eanstruction could not prevent a net 1 ass in the tatal value of building permits issued in 1979.

A second and related visible indicator of growth rate is the number of "For Sale" signs that dot the horiagn, and the length of time they stay before being replaced by "Sald" Winnipeg was clearly a buyers martiet, with oniy 26. gercent of the 20, 121 listings being sold. Edmanton was a much more active marlet With 46 percent of the 17,460 units being sold (2). The 1 arger number of listings in Winnipeg is deceiving. It should be pointed out that the slower the market, the more libely houses will nat sel and therefure will be listed again after the termination of 
the first agrement.

A third visible indicator of growth is the extent or change required in the transportation systemin Eetween 1976 and 1980 daily communters in Winripeg increased from 245,000 to $201,000,0$, 6.6 percent. In the same period, commuters in Edmonton increased from 24. 000 to 298,000, a growth of 22.6 percent. Edmanton's response was the messive public transit project knawn as the LFT in addition ta construction of major thorgughtares. While Wirripeg detated rapid transit plans or five occasions between 1757 and 1980 : nothing in fact was built (Lowe, 19g5).

\section{Sociai Science Ferspectives on Fiapid Growth}

Very early in the discipline of sociology, rapid papulation growit was an impartant topic. Durtiteim (1933), and Simel (1750) addressed the issue, highlighting respectively the social structuraI and psychological consequences of rapid growth Howeyer, the Chicago Schoo] of sociology became e principal source of comment an the effects of rapid growth. This is rot surfrising.

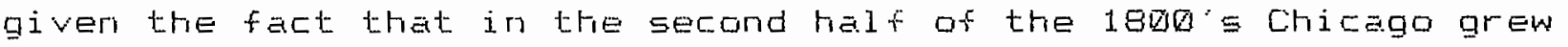
by one million people. The turn of the century did not Iead to a declime in this trend. Wirth's hypothesis (1938) on the consequences of size, density and heterogeneity was the classical formulation of the percejved problem. Wirth. however, 
did cantrast growth in isolated trading centres in the midet of agricultural regions to thriving world ports and commercial and inoustrial connurbations, where the consequences may be more dramatic.

The "modernization" Iiterature suggests there are some distinct advantages to the openness that comes with rapid change, as well as to the economic prosperity that results (Inteles and Smith, 1974). This Iiterature tends to focus on developing nations, however, and therefore may not be as useful for understanding rapid change within an industrialized setting.

Freudenberg summarizes the 1 iterature ori grouth, and concludes, "it is passible to draw competirg hypatheses either from the broader sociological it iterature or from work focusing specifically on rapidly growing communities" (1984:699). He argues that the issue is whether rapid growth disrupts the social structure sufficiently to lead residents to negative assessements of their community and their own quality of life, or whether the rapid growth affers such new and exciting apporturities that residents perceive the growth positively and see it as entancing the quality of their lives.

Fischer suggests research in this area is long averdue. "Frobably the greatest need for clarification lies in the realm of urban social psychology: conceiving the nature of the irdividual's 
place iri interaction with the urban structure" (1975:76). He Further notes, "The bulk of urban research is compased of Ethmagraphic studies of single communities. These warks provide points of comparison but no actual comparisons of different communities" (1975:81). Through the vehicle of the winnipeg arid Edmontor Area Surveys of 1781 we have the unique opportunity to compare perceptions of the city care aspect of individual interaction with the urban structure), in a slow and a fast growth city, holding constant the region of the country, the size af city, the time of analysis ard the methodolagy used (Z).

\section{Methodalogy}

In 1981 the winnipeg Area Study and the Edmorion Area Study Employed a cammon sampling design, questianraire, and data collection and coding techniques. The interviews were conducted during the same time period, February through farch. This was just

prigr to the beginning of an econamic recession. Trained interviewers administered the survey instrument in one haur interviews wi.thin the household setting.

The primary sampling unit was the housetiold. A simple rendom sample of al1 addresses 1 isted in the 1980 assessement file for the City of Winnipeg and a simple random sample of all adresses compiled by the city of Edmonton from their 1980 enumeration were selected. Within the household one eligible person was selected from 
arrong those for whom the dwelling was the usuel. place of residence and who were 18 or alder. Interviewers were given detailed guildejines on how to obtain an equal number of male arid female resporidents within their giver allotment of addresses. First contact with the households was betweer $4: 30$ ard $8: 30$ p.m. or weEl:days or or weeterids. In Winnipeg. 457 addresses were selected and a response rate of $74 \%$ resulted in scb completed interviews. Ir Edmonton, 543 addresses were selected, and a respange rate of $75 \%$ resulted in a final sample of 4 ge comparisons with census data showed the samples to be representative of the cities fram which they were taken in important demographic aspects ifinael, 1981 ș Currie and Thacher, 1792 ).

Measures of Evaluation of the city ard of Lrban Growth

The questionnaire included a series cf 18 characteristics of the city presented in a sementic differential scale with a seven point range. Examples irclude attractive-unattractive, good place to raise children-porr place to wajse childrer, safe-unsafe, etc. (For the camplete list of items, see rable 2 ). Dhe of these items was "too little growth-too much growth", our key measure for the Exaluation of growth. There was as well, a second measure of the j.mpact of growth. In a later section of the questionraires respondents were asked to rank what they felt were the three most important environmental issues facing their Frovince. Thirteen options were provided, ircluding "Cortrol of Growth rurban, industrial)" All those who ranted "control of growth" as orie of 
the three most important issues were grouped into one category, thus forming a dichotomous variable.

A Madel of Community Satisfaction

To explain community satisfaction, a model was developed on the basis of previous work dane by Marans and fodgers (1975). The moded. is outlined in Chart 2 . Satistaction with the city was the dependent variable. In attempts to predict satisfactian, "which attributes are most relevant is an empirical question" Marans and Foger"s suggest. Several types of environmental attributes were included in the model. First, those variables closest to the individual included housing characteristics, degree of integration within the reighbourhood, and general social relationships that can be subsumed under the heading of status community (Stub, 1974). These items represent the possibility of social relationships without the spatial component being dominentu however, they are potentially important for overall satisfaction with the city. The next series of variables were single item indicators of overall satisfaction with housing, the neighbourhood, friendship and family life. The third series of variables were the attributes of the city. These were the 18 variables in the semantic differential scale mentioned above. In addition, a standard of evaluation, the standard against which an attribute is evaluated, was included. For example, the place of birth, as well as the length of time the person has resided in a community may well affect his or her assessement of the community. Finally, person characteristics, 
such as age and education, can irfluerce the perceptions and evaluations of the attributes and therefore need to be included. Eeginning with the dependent variatle, we shall naw discuss each of these gereral categories of variables as well as the specific measures used.

\section{Satisfaction with the City and Evaluation of City Attributes}

Drice the item on growth was extracted from the semaritic differentiel items, a factor anelysis was then ferformed on 16 remaining items (4). In Edmonton, five factors emerged with the eigenvalue set at 1.0. The cumulative percentage of variance explained was 57.3 . In Winnipeg, six factors eirerged, and the variance explained was 6S.7 percent. In botti cities, all items loaded on one of the factors with a minimum loading of $=40$. In both cities, the same three items had the highest laadings on the first factor. Because of this, and because of the gereral rature of the three items ipleasantress of the city, goad place to live and attractivel it was decided to take these out of the cluster ard consider them an irdex to be called Satistaction with the City. This index was used as the dependent variable in the analysis.

\footnotetext{
The strategy then adopted was to create the followirg scales composed of items that logically fit together. These variables were the measures used to assess attributes of the city.
} 


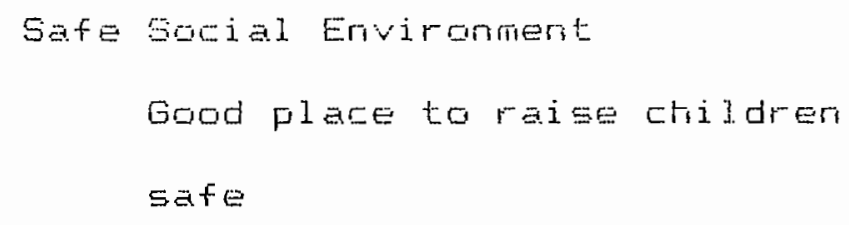

Frieridly environmert

Good for matimg friends

Frieridly people

Lots of things to do

Good Frysical Enviromment

Ciean air

Eiood eI imate

Economic Climate

Good economic cIimate

Good charices to get ahead

Econamic Boom factors

Good choice of housing

Ease of getting around

Local. S/Cosmopolitars

Uncrowdedicrowded

rural/big city

Measures of Satisfaction with Housing, Neighagurhogd, Friendship and

Family

Measures of satisfaction with housirg, neighbourhood, friendship and family were sirgle item questions, coded from (1) very dissatisfied to (7) very satisfied. They have been used in the annual Edmonton Area Study sirce 1977 (See fernedy et al. 1977). 
These questions were taten from the 1974 Michigen Guality of I ife Survey and the National Gpinjon Fiesearch Council Surveys.

Seventeen variables, all indicators of housing characteristics, integration in the neighbourhood or status cammunity were looked at as possible contributors to overall satisfaction with housing, neighbourhood, friendship and family respectively, and as predictors of satisfaction with the city. A complete list of the variables used in this stege af the analysis can be found in the Appendix. Two analyses were perfarmed. First, a correlation matrix was run and variables that were urcarrelated with both the dependent variable (satisfaction'with the city) and the other relevarit measure of satisfaction were dropped. ottier items deleted included thase cases for which the correlation was so high that two variables were in fact measuring the same thirg. The remaining variables were then entered into a step-wise regression analysis to test their ability to predict the related overall satisfaction measure: housing, neighbourtood, friendstip or family. Dne of these variables modestly predicted satisfaction with housing (those in single dwelling units), arother, satisfaction with neighbourhood (adults bnown by name in reighbourhood), and a third, frierdship satisfaction (frequency of getting together with friends). However, none of these variables were significantly correlated with satisfactjon with the city when the significance level for remaining in the model was set at a liberal p. .15 in at least one of the two cities. This is the standard SAS default option. For that reason they were dropped from further analysis. 
Standards of Evaluation and Fersonal Characteristice

Marans and Fogers (1975), as weil as others (e.g. Campbeil, Converse ard Rodgers, 1976, Loetscher, 1981) have pointed ta the importance of locating the standard by which people evaluate the enviromment in which they Iive. These standards of Evaluation mey significantly affect the level of satisfaction experienced by residents. In addition, the persomal characteristics of individuals may be significant contributors to satisfaction, although Marans and Fogers suggest they have an impact only indirectly on levels of community satisfaction. Ten variables were examined rsee fippendix). The same procedures as autined above were used to determine thase that would be retained in the madel. Eight Variables were retained for further analysis.

FINDINGS

\section{Evaluations of Growth}

Fesidents of the two cities had significantly different evaluations of the growth rates of their cities (Table $\Xi$ ). On the semantic differential item on growth, 42 percent of winnipeggers judged the growth of the city to be about right, neither too 
little nor too much. Ar almost equal percentage considered the growth to be tao little. Ori the other hand. two thirds of Edmontanians considered their city's growth to be too much and a quarter judged it about right. Only 7 percent cansidered it too 1 ittle.

On the questions about the envirarment, anly 12 percent af luminipeggers chase the item "contral af grawth (urban! industrial)" as a first, secand ar third most importarit ervirarmental issue facirg Maritoba. This placed growth as anly the tenth most frequently mentioned issue aut of thirteen. Issues of main concern to residents were "conservation of resources" $(4.5 \%)$ " "water quality" (SB\%) "control of chemicals or waste (Sด\%). Almost twice as many Edmartorians (22\%) checked growth as an imfortant environmental issue. Its ranking was also much higher. Sth, ance again after "control of chemicals or waste" (47\%), "conservation of resoumces" (42\%) and "water quality" (ङ1\%).

We shall have accasion shortly to measure the impact of these assessments of growth on the residents' evaluation of other city attributes, as well as or satisfaction with the city"

Evaluation of City Attributes

Several analyses were performed or these data. First of all, the mean scores an the 18 semantic differential items indicate that the residents of bath Winnipeg and Edmantan were cansistently 
positjve in their perceptions of aspects of their city (Tate 2 ). This in itself deserves attention. A great deal of media coverage, which highlights urban problems, seems to imply that residerts do not thint: highly of their city. In addition, Charles Gordan (1984) argues that images of the city are not created by the residents themselves but by the visitors. These peaple tend to stay in the downtown hatels, never visit the suburbs, laok for action rather thar peace and quiet, and in general, seel: different amenities than the residents. Yet it is their vision of the city that is popularized and becames the basis for the reputation of the city.

There were same differences between the cities. On all but two items, Winnipeggers gave a higher evaluation of Winnipeg than Edmontonians did of Edmonton. These differences were statistically significant (p. ags) on nine variables). One can abserve in Table 2 that the differences in rrean scores accur precisely on thase items ane would suggest should be influenced by differential grouth rates. These evaluations follow rather consistently what the traditional theories of rapid growth have suggested. That is, the ecanomic measures, econamic climate and chances to get atread, were evalallated significantly more positively in fast growing Edmanton. Winnipeggers, on the other hand, rated their city higher on social characteristics such as friendiness, good place to raise children, and being safe, as well as some physical aspects such as clean air and uncronded city. Winnipeg was also judged more positively by its residents as easy to get arolind in (5) and having 
good choice of housingn

We then wished to ascertain whether ar not the differential evaluatior of growth by the residents tiad an impact on these variables. The samples of both cities were each divided into three groups: those assessing the growth as tog much rscores $5,6,7$ on Table $\Xi)$ about right $(4)$ and too jittle $(1,2,3)$. The mesn scores on the attributes of the city were calculated orce again, and $T$ tests used to test the significance of difference (p Y bs) between the evaluating groups within each city (b). Forty-eight T tests were rur for Each city (16 varjaties, G groups).

In Edmonton: only four differences were significant. As one might expect, those who thought the growth was tog much were significantly more 1 ibely to find the city crowded compared to the those who thaught the growth was too little (p. $\checkmark$. Q2) or just rigtit (p. ¿obol). The same group also had significantly 1 ower scores than the other two groups on clean air ljust rigtit, p. b. os: too little, $p .<.002$. Beyand this, there was littlediscernable pattern. Those who thought growth was abgut right rarely had the highest or lowest scores on any variables. but tended to score closer to those thinking grawth was too much. On the other hand, thase wha thought the growth was too ljttle were most positive about the city as a place to raise children and a as sate place. but also scored lowest of the three groups on "easy to get araund in" "good for matimg friends" and "gaod hausing choices". 
In dirnipeg, differential assessements of growth were associated with differences on other variables more frequently and more consistently. First of all, those thinting the growth was about right gave the most positive evaluation on 10 of the 16 items. Secondly, sixteen group comparisions out of 48 were significantly different (7). This involved nine variables. Six of these variables had significant differences within winnipeg in the same direction as that which accured between cities. For example, just as those in the slower growth city scored the city higher as safe and a good place to raise children, so also, within the slower growth city those who saw the growth as too little also had the highest evaluation of the city as safe and a good place in which to raise children in all four cases. $P<.01$ ). On the other three variables, there were significant differences within Wirnipeg that did not occur between winnipeg and Edmonton. That is, those who viewed the growth as about right also were more Iitely than the slow growth evaluators to see Wimnipeg as a big city, with lots to do and with a good climate. Finally, it is interesting to note the differential evaluations on the economic indicators. Those perceiving too little growth ance again score lower than the ather two groups on economic climete and chances to get ahead, with three of the four differences being significant.

\section{Levels of Community Satisfaction}

We have seen that wimnipeggers were equaliy likely to thint: 
that the growth of their city was too little or about right. Edmontonians were much more likely to think their city's growth was too much. Given that information we then wished to assess overall satisfaction with the city. Several questions were addressed. First, how much of the variance in satisfaction with the city could we explain in each of the two cities? Secondly, do the same variables and/or clusters of variables account for satisfaction with the city in Wirnipeg and Edmonton? Finally, is the assessement of growth in each of the cities a significant factor in residents. satisfication with the city?

In order to answer these questions, two regression procedures were employed. First, four independent, preliminary stepwise regression procedures were carried out to determine the variables in each group (personal characteristics, standard of evaluation, housing and social relations, and city characteristics) that would predict satisfaction with the city. It should be recalled that the variables measuring housing characteristics, neighbourhood integration and status community had already beer el iminated. In this step, once again a number of variables did not turn out to be statistically significant contributors to overall satisfaction with the city (p. $Y .15$ in either of the twa cities). This stepwise procedure determined both the variables that were to be included in the next step as well as their order within their group. The four groups of variables were then successively entered into one hierarchical regression so that the second and subsequent groups of variables were not entered into the regression until the preceeding 
group's explanatory power had been Exhausted.

As Tables 4 and 5 indicate, the model explained almost equal amounts of the variance in each of the two cities, about 42 percent. This explanatory power is relatively strong.

In spite of an ambitious attempt to use a large number of variables to predict levels of satisfaction, our results indicate that in fact a relatively small number contributed to community satisfaction. When a much larger number of the variables were entered (2S in fact) into a regression equation without grouping, the total adjusted $r$ squared for Winnipeg was 44.8 percent (F=24. 3 ) and for Edmonton was 47 percent (F=28.0). This suggests that the madel adopted made a parsimonious use of the variables available to explain community satisfaction.

The groups of variables did not explain equal amounts of variance in the two cities, nor did the variables within the groups betiave in the same manner in the two cities. Specifically: personal characteristics and standard of evaluation contributed 19 percent of the variance in Edmonton but only 7.4 percent in Winnipeg. Gn the other hand, neighbourhood and friendship satisfaction were much stronger in Winnipeg. 14.6 percent compared to 4 percent. Attributes of the city explained virtually the same amount of variance in the two cities, about ore half.

The variables that had different explanatory power in the 
two cities cari be best identified by comparing the unstandardized b scores in Tatles 4 and 5 . There we see that Edmonton was more satisfactory to those who were born in Edmonton (1.05, compared to -.65 in winnipeg), preferred the suburts (1.30 compared to . . Winnipeg) and had children at home (.95 compared to -..5). While family life satisfaction was the same in the two cities, neighbourhood and friendship satisfaction was stronger in winnipeg (.6.5 and .5 .5 in Winnipeg compared to . 3.5 for both measures in Edmoritori).

In addition to noting the variatles that contributed to satisfacticn with the city, it is useful to point out those that were not predictive. First, neither measure of growth lit's evaluation as too little or too much, nor the'identification of growth as an important environmental issue) appeared in the equation. This was one of the key questions we set out to address in the paper.

The other most rotable absentee was the economic index lgood economic climate and good chances to get ahead). We saw that as iridividual items, their mean scores were significantly stronger in Edmonton. Those ir winnipeg who tended to view growth as too little had the lowest scores on the economic items, but in neither Edmonton nor winnipeg did ecomomic growth predict overall satisfaction with the city, at least as measured in this study.

What is perhaps equally interesting is the relative lact: of significance of these economic variables in another aspect of the 
study- In order to assess the usefulness of the subjective perception of satisfaction with the city we decided to treat satisfaction with the city as an independent variable. Our goal was to see if it could predict the likelihood of residerits deciding to stay in the city rather than move. Four personal characteristic variables and nine subjective perception variables, including the economic index as well as satisfaction with the city, were entered into two independent stepwise regression equations (8) to predict decision to stay in the city. Those variables that were significant (p. (15) ir at least one (ity) were retained, and a hierarchical regression was then performed, with the personal characteristics entered first. In Edmonton, the total variance explained was 15.8 percent. The perception variables, including'satisfaction with the city, in fact explained more of the variance than the personal characteristic variables $((9.2 \%$ compared to $6.6 \%)$. The economic index was not significant. In Winnipeg, the total variance explained was 12.5 percent. Personal characteristics had slightly higher predictive value than subjective evaluaticns $16.6 \%$ compared to $5.8 \%$ ). The economic index again was not significant. While the importance of satisfaction with the city and the other subjective evaluations varied between the cities, and the amount of variance explained by these variables was not particularly high, they did add enough explanatory power to argue that they should not be ignored in future research. Finally, it is noteworthy that for the total sample, the subjective economic indicators were not the strong predictors ore might expect them to be. 


\section{Coric Iusions}

The actual growth rate of the population did appear to influence the evaluations of attributes of the city by its residents. Eletween city comparisons suggest that thase residing in the slower growth city tended to evaluate their city attributes more positively, except on the economic variables. Within city comparisons suggest that differential evaluation of growth tended to have a greater impact in the slower growth city. There, once again, those viewing the city growth as about right or too little were mare positive in their assessment of city attributes, except on the economic váriables, where the slow growth evaluators gave the lowest scores to these items.

We were able to predict an equal amount of the overall satisfaction with the city in both localities. While city attributes were the most powerful predictors in both cities, evaluation of growth of the city did not appear to have a positive or negative impact on overall satisfaction with the city. Characteristics associated with family life were the next most powerful predictors in Edmonton, while social retworks were better predictors in winnipeg. These findings are consistent with what one might expect; that is, in rapid growth situations, the more narrow social networks of the family would take an more significance than those in the broader community, even if growth itself was rot perceived to be an important variable by the 
residents.

The findings indicate clearly that residents did not tend to perceive growth in strongly negative terms as some of the classical literature would suggest. One could arque that the cities studied are not 1 arge enough to provole the negative reactions suggested by earlier authors. On the other hand, it may be that the Edmonton city government simply moved quickly to alleviate the most abvious inconveniences that could arise from rapid growth so that it was not perceived to be terribly disruptive. Or, finally, one might argue that Edmonton was so Iarge with a population of 450 , gog that even an increase of 16 , 000 pecple in a 10 year period did not provot:e significant discomfort. Earlier studies did not measure the subjective impact of growth; they only implied negative subjective impact. These implications may, in fact, have been unwarranted, at least for the majority of the urban population.

It may simply be that rapid change must have direct consequences on the individual for it to have a significant impact. Fennedy's research on Edmortan concludes that economic conditions of boom and bust do have same effect on subjective well-being "but this is clearly buffered though the adjustments made on an individual level to one's own personal circumstances" (1985). Freudenburg's research on boom towns in Colorado (I984) is further support for this view. The arrival of 1900 construction workers in a town of sodo leaves very few untouched. Yet even there, Freudenburg comments that the adults seemed "able to continue the 
mare intinate portions of their ljves relatively unchanged." The yourig, on the other hand, had new classmates in school every day. "Students were undergoirg a significant transition in their personal lives at the same time that the social world around them was going through a substantial change of its own" (1984:702). Greeley (1781:16) summarizes this point best when he suggests that our surveys of happiness and well-being really measure what is "iritimate, personal, private." Only when the "impersonal becomes so threatening as to destroy intimacy" will we see a major impact on public perceptions and evaluations. 
1. The 1981 winnipeg Area Study acknowledges with thanks funding received from the Fopulation Fiesearch Laboratory, University of Alberta, the Social Sciences and Humanities Fesearch Council. The Institute for Socjal and Economic Fesearch, University of Manitoba, and the Fiesearch Boards of the Universities of lianitoba and wirnipeg. The authors are particularly grateful to Frofessor Leslie w. Kennedy for his encouragement and assistance in undertaking this first of the Winnipeg Area Studies. We also wish to thart: Aridrew Wister for his assistance, and Ms. Mary Anine kandract: our research assistant on this project.

2. The Multiple Listings Service (MLS) statistics for Winnipeg, unlite Edmonton, include all properties for sale. However; aver 90 percent of thase properties are houses.

3 . It must be lept ir mind that we are comparing two cities at are point in time. We are therefore unable to assess whether the residents of the cities had similar or different levels of satisfaction during previous time periads.

4. The item "too close to relatives, too far from relatives" was omitted because scoring presented serious problems.

5. Data on "Time to Wort:" published by Statistics Canada reveals that Edmontonians" average time to get to worl: was the same as that of Winnipeggers over the years $1970-80$ in spite of the tremendous increase in road construction in Edmonton and in the rumber of rew daily commuters. The construction of the LFT would appear to be a logical Explanaticn. However, there are two rather contradictory pieces of evidence. On the ore hand, perceived availability of public transportation by residents between $1977-80$ went down in Winnipeg from 83 to 77 percent and from 71 to 60 percent in Edmonton. On the ottier hand, use of public transportation by those who perceived it to be available went up in Winnipeg from 30 to 32 percent and in Edmonton from 24 to 27 percent. While actual time to wort: may not have varied, perceived inconveriences ceused by construction may have led to the less positive subjective perceptions of Edmontonians.

b. The p a do is a relatively liberal test in this instance, because of the fact that the measures are all within the same sample. The actual significance levels have been reported so that those preferring a more conservative test may note the actual findings.

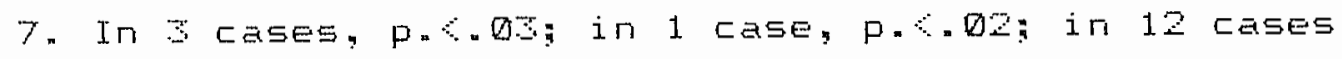
$P=\odot 1$.

8. Variables included were the following: age, sex presence of children, household income, grouth of city, distance from relatives, satisfactian with, the city, and all six indices of city attributes described on P. 14 . 


\section{AFFENDI $X$}

VAFIABLES INCLUDED IN INITIAL ANALYSIS

When appropriate the variables were recoded to be entered as dummy variables.

Housing Characteristics

Number of rooms

Type of divelling

(single tiutse, elevatar apt)

Integration into Neighbourhood

Number at adults knawn by rame ir neighbourhood

Frequency of getting tagether with rieighibours

Length of time in residence

Seriously considered moving within city

Assessment of increase of crime in neighbourhaod

How safe feel walking in neighbourhood at night

Owried or rented

Status Community

How ciften get together with frierids

Family relationships improved sirice move to city

Friendships improved since move to city

Number of organizations belonged to

Illness of someone close in last year

Death of someone close in last year

Wort: related difficulties in past year

Growth a major Envirommental issue

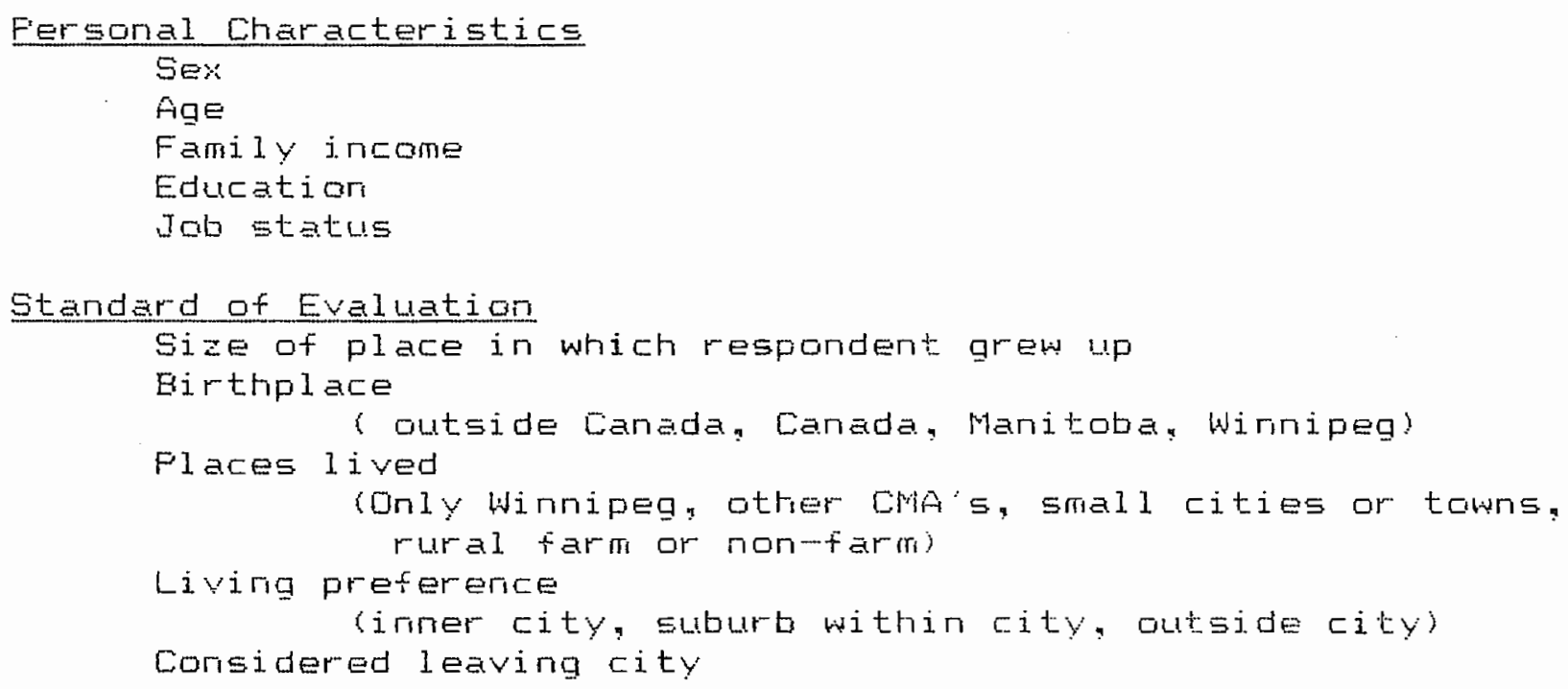


CHART 1: Dollar Value of Building Permits Issued in Winnipeg and Edmonton 1971-80

DOLLARS

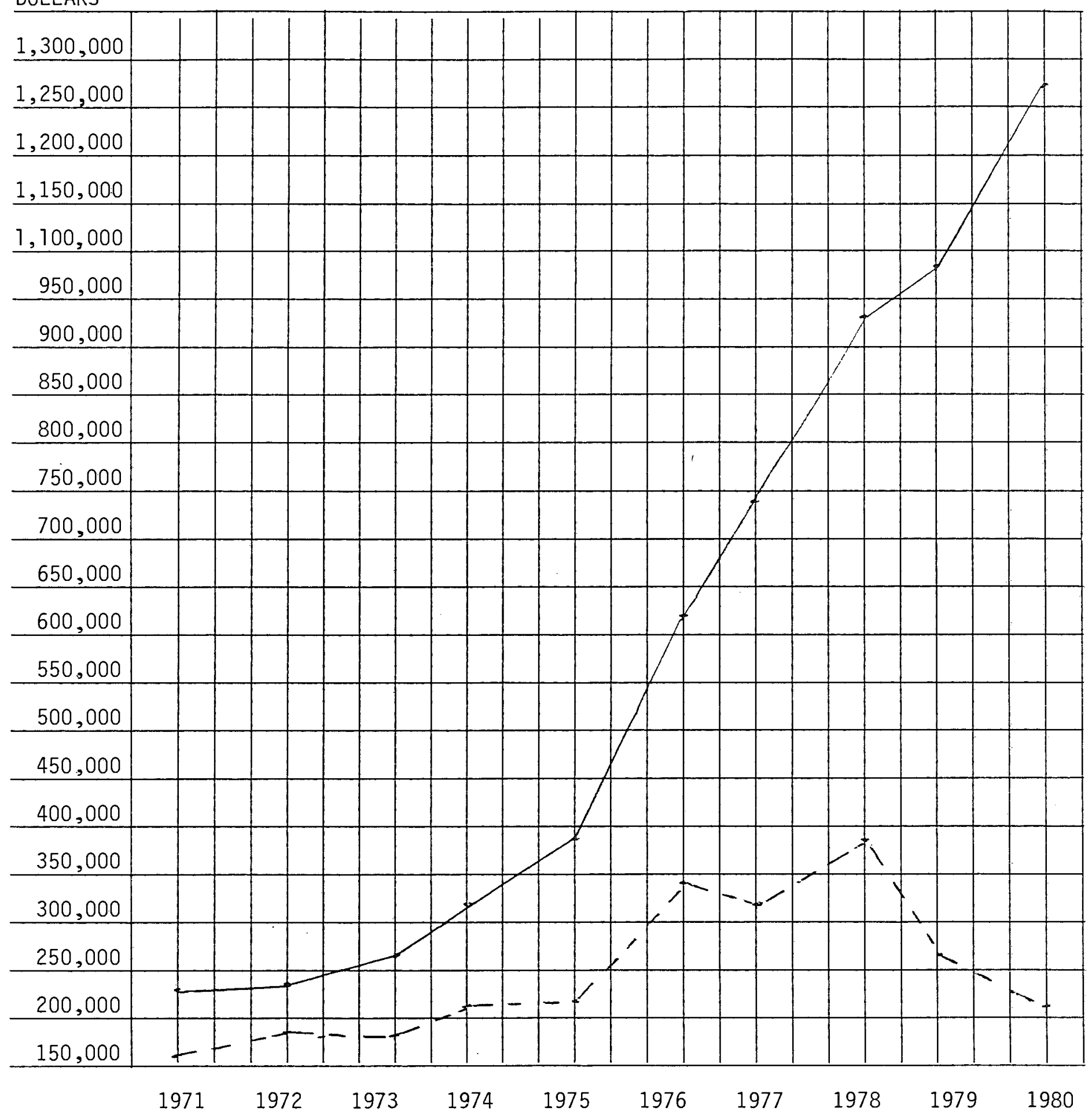

Winnipeg Edmonton

Source: Statistics Canada, Annual Survey of Building Permits, Cat. 64-203. 
Chart 2. Model of Community Satisfaction

\begin{tabular}{|c|c|c|}
\hline & & $\begin{array}{l}\text { DEFENDENT } \\
\text { VAFIIABLE }\end{array}$ \\
\hline $\begin{array}{c}\text { personal } \\
\text { characteristics }\end{array}$ & $\begin{array}{l}\text { standard of } \\
\text { evaluation }\end{array}$ & \\
\hline
\end{tabular}

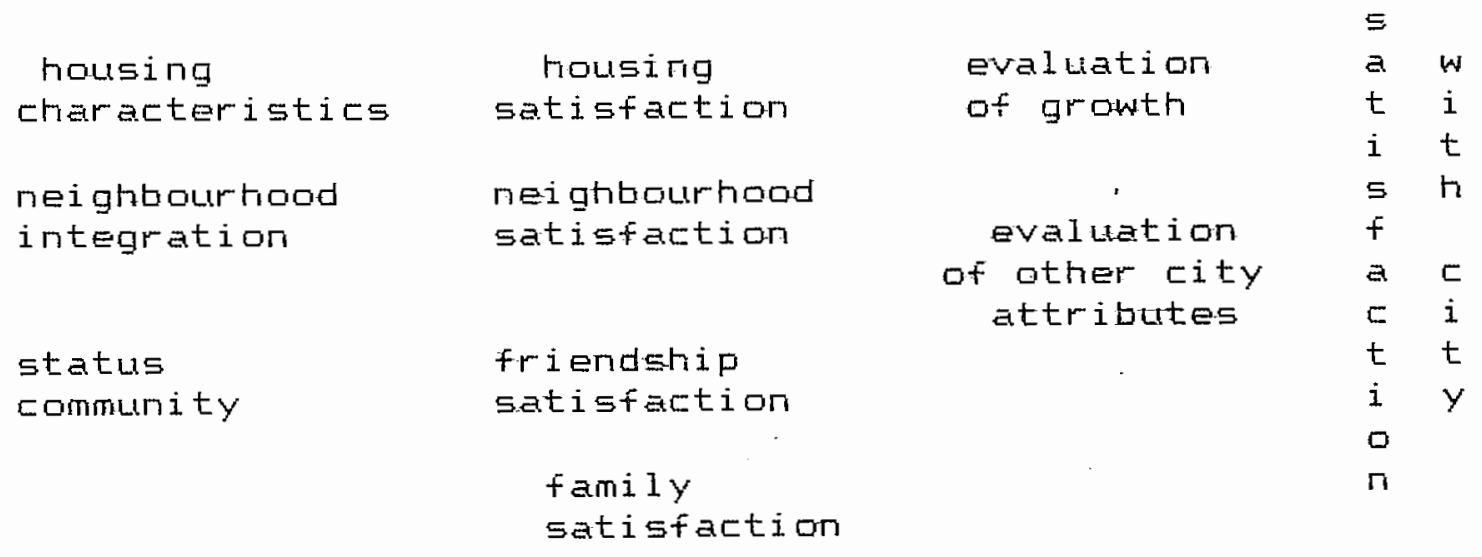


TABLE 1. Population Growth, Winnipeg, 1871-1981, Edmonton 1901-1981.

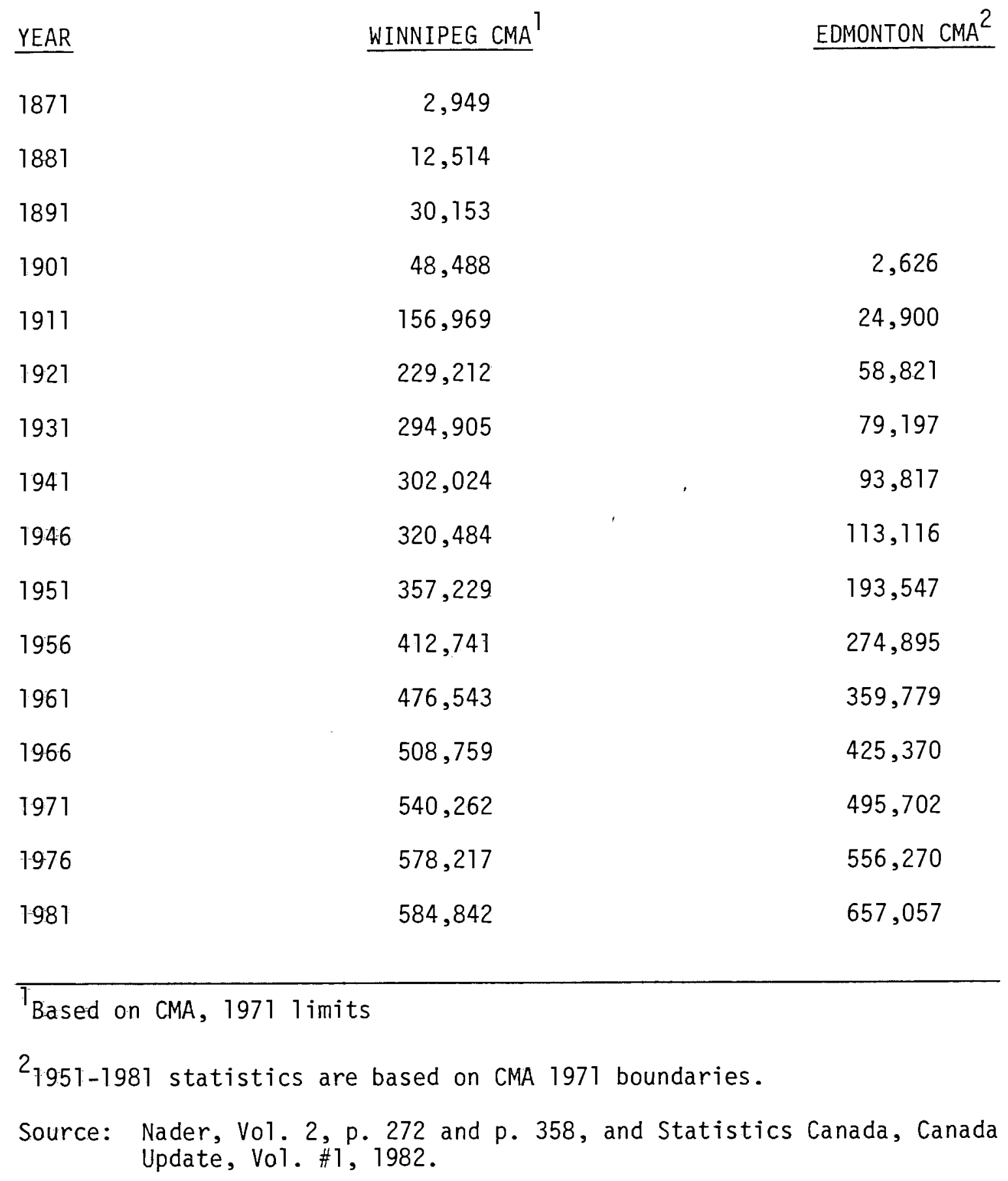


TABLE 2: Mean Scores on Perceptions of the fity by Residents of Winnipeg and Edmonton

\begin{tabular}{|c|c|c|c|c|}
\hline & & WINNIPEG & EDMONTON & \\
\hline 1. & *Attractive & 5.27 & 5.04 & Unattractive \\
\hline 2. & Unfriendly people & 5.47 & 5.04 & Friend7y people* \\
\hline 3. & Crowded & 4.68 & 3.74 & Uncrowded ${ }^{\star}$ \\
\hline 4. & Good place to live & 5.58 & $5.5: 5$ & Poor place to live \\
\hline 5. & Pleasant & 5.60 & 5.47 & Unp leasant \\
\hline 6. & Big city & 4.99 & 5.52 & Rura 1 \\
\hline 7. & Nothing to do & 5.48 & 5.45 & Lots of things to do \\
\hline 8. & Hard to get around in & 5.60 & 4.96 & Easy to get around $i^{\star}$ \\
\hline 9. & *Good place to raise children & n 5.25 & 4.48 & Bad place to raise children \\
\hline 10. & $\star$ Safe & 4.89 & 4.26 & Unsafe \\
\hline 11. & Poor climate & 4.31 & 4.42 & Good climate \\
\hline 12. & ${ }^{\star}$ Clear air & 5.42 & 4.68 & Dirty air \\
\hline 13. & Poor economic climate & 3.72 & 5.37 & Good economïc climate* \\
\hline 14. & Too little growth & 3.57 & 5.79 & Too much growth \\
\hline 15. & Too close to relatives & 4.22 & 4.41 & Too far from relatives \\
\hline 16. & Bad for making friends & 5.30 & 4.96 & Good for making friends* \\
\hline 17. & Bad choice for housing & 5.50 & 4.75 & Good choice for housing* \\
\hline 18. & Poor chances to get ahead & 4.60 & 5.68 & Good chances to get ahead* \\
\hline
\end{tabular}

1

Items were scored on a seven point scale. Items are ordered as they were on the questionnaire. However, for the analysis the scores have been reversed for items $1,4,5,6,9,10$ and 12 so that the more positive choice always is scored at the high end of the scale.

Significant differences $p<.05$ are indicated by *. 
TABLE 3: Evaluation of Growth by Residents of Winnipeg and Edmonton

\begin{tabular}{|c|c|c|c|c|c|}
\hline & & \multicolumn{2}{|c|}{ WINN I PEG } & \multicolumn{2}{|c|}{ EDMONTON } \\
\hline & & No. & $\%$ & No. & $\%$ \\
\hline \multirow[t]{6}{*}{ Too Litt]e } & 1 & 33 & 10.2 & 7 & 3.7 \\
\hline & 2 & 41 & 12.7 & 6 & 1.5 \\
\hline & 3 & 55 & 17.0 & 14 & 3.5 \\
\hline & 4 & 137 & 42.3 & 112 & 28.0 \\
\hline & 5 & 31 & 9.6 & 83 & 20.7 \\
\hline & 6 & 14 & 4.3 & 93 & 23.2 \\
\hline \multirow[t]{2}{*}{ Too Much } & 7 & 13 & 4.0 & $\underline{85}$ & 21.2 \\
\hline & & $(324)$ & 100.00 & $(400)$ & 100.00 \\
\hline Mean & & 3.57 & & 5.19 & \\
\hline S.D. & & 1.52 & & 1.37 & \\
\hline
\end{tabular}

Difference of means is significant, $p<0.000$. 
TABLE 5: Regression Analysis for Satisfaction with City by Hierarchically Grouped Data for Winnipeg

\begin{tabular}{|c|c|c|c|}
\hline & $\underline{\text { BETA }^{1}}$ & $\underline{b}$ & $\underline{r^{1}}$ \\
\hline $\begin{array}{l}\text { Personal Characteristics } \\
\text { age of respondent } \\
\text { presence of children } \\
\text { household income }\end{array}$ & $\begin{array}{r}.18 \\
-.05^{\star} \\
.08^{\star}\end{array}$ & $\begin{array}{r}.03 \\
-.36 \\
.01\end{array}$ & $\begin{array}{r}.18 \\
-.09 \star \\
.09 \star\end{array}$ \\
\hline \multicolumn{4}{|l|}{ adjusted multiple $\mathrm{R}$ sq. $=3.5 \%$} \\
\hline $\begin{array}{l}\text { Standard of Evaluation } \\
\text { size of place where grew up } \\
\text { living preference (inner city) } \\
\text { living preference (suburbs) } \\
\text { not considered leaving city } \\
\text { birthplace--Winnipeg }\end{array}$ & $\begin{array}{l}.14 \\
.05 \\
.05^{\star} \\
.19 \\
-.08 \star\end{array}$ & $\begin{array}{r}.24 \\
1.09 \\
.33 \\
1.37 \\
-.65\end{array}$ & $\begin{array}{l}.10^{\star} \\
.13 \\
.03^{\star} \\
.23 \\
-.004^{\star}\end{array}$ \\
\hline \multicolumn{4}{|l|}{ adjusted multiple R sq. $5.9 \%$} \\
\hline $\begin{array}{l}\text { Housing and Social Relations } \\
\text { neighbourhood satisfaction } \\
\text { friendship satisfaction } \\
\text { family life satisfaction }\end{array}$ & $\begin{array}{l}.28 \\
.22 \\
.04^{\star}\end{array}$ & $\begin{array}{l}.63 \\
.53 \\
.71\end{array}$ & $\begin{array}{l}.37 \\
.29 \\
.12\end{array}$ \\
\hline \multicolumn{4}{|l|}{ adjusted multiple $\mathrm{R} s q .=14.6 \%$} \\
\hline $\begin{array}{l}\text { City Characteristics } \\
\text { safe family environment } \\
\text { good physical environment } \\
\text { friendly environment } \\
\text { locals/cosmopolitan }\end{array}$ & $\begin{array}{r}.31 \\
.13 \\
.13 \\
-.08 \star\end{array}$ & $\begin{array}{r}.35 \\
.16 \\
.11 \\
-.10\end{array}$ & $\begin{array}{r}.45 \\
.48 \\
.40 \\
-.02^{\star}\end{array}$ \\
\hline adjusted multiple $\mathrm{R}$ sq. $=18.9 \%$ & & & \\
\hline $\begin{array}{l}\text { cumulative adjusted } R \text { sq. }=42.9 \% \\
N=336\end{array}$ & & & \\
\hline
\end{tabular}


BIBLIOGRAPHY

Artibise, Alan.: 1977, Winnipeg, An Illustrated History (James Lorimer and Company, Toronto).

Campbe11, Angus, Phil ip E. Converse, and Willard L. Rodgers: 1976, The Quality of American Life. (Russell Sage Foundation, New York).

Canada Year Book: 1978-79, Table 14.16, p. 615.

Currie, Raymond F. and Charlene Thacker: 1982, Selected Findings From the 1981 Winnipeg Area Study. Edmonton Area Series Report No. 22, (University of Alberta, Edmonton).

Fischer, Claude: 1975, "The Study of Urban Community and Personality" Annual Review of Sociology, pp 67-98.

Freudenberg, William R: 1984, "Boomtown's Youth: The Differential Impacts of Rapid Community Growth on Adolescents and Adults," American Sociological Review, Vol. 49 (October: 697-705).

Gordon, Charles: 1984, "Visitors Who Spurn Our Cities," Maclean's magazine, April 30, p. 13.

Greeley, Andrew: 1981, "The State of the Nation's Happiness." Psychology Today, Vol. 15 (1), 14-16.

Inkeles, Alex and David H. Smith: 1974, Becoming Modern: Individual Change in Six Developing Nations. (Harvard University Press, Cambridge, Ma.).

Kennedy, Leslie W: 1985, "Effects of Social Change on Wel1-Being: The Edmonton Experience." Social Indicators Research, forthcoming.

Kennedy, Leslie W., Herbert C. Northcott and Clifford Kinzel: 1977, Quality of Life in Edmonton: Initial Findings from the 1977 Edmonton Area Study. Edmonton Area Series Report No. 1, (University of Alberta), June.

Kinze1, Clifford: 1981, Selected Findings from the 1981 Edmonton Area Study. Edmonton Area Series Report No. 20, (University of A1berta), August.

Loetscher, Lienhard: 1981, "The Quality of Life in Canadian Metropolitan Areas: Conceptual Framework for a Comparative Study. Urban Studies Working Paper No. 4, (York University, Toronto).

Lowe, Jeffery: 1985, "The (Non) History of Rapid Transit in Winnipeg", City Magazine Vol 7, No. 2, pp. 22-31.

Marans, Robert W. and W. Rodgers: 1975, "Toward an Understanding of Community Satisfaction" in A. Hawley and V. Rock, Editors, Metropolitan American in Contemporary Perspective. (John Wiley \& Sons, New York), pp. 299-354. 
Nader, George A.: 1976, Cities of Canada, Vol. 2: Profiles of Fifteen Metropolitan Centers. (Macmillan of Canada, Toronto).

Perspectives Canada 111: 1980, Ottawa, Ministry of Supply and Services, 1980 , p. 192.

Simme1, Georg: 1957, "The Metropolis and Mental Life" in P.K. Hatt and A.J. Reiss, Jr. (eds.) Cities and Society. (The Free Press, New York) 635-646.

Statistics Canada: 1981a, Annual Summary of Building Permits, Cat. 64-203.

Statistics Canada: 1981b, Selected Population, Dwelling, Household and Census Family Characteristics, for Census Tracts, Edmonton, 95-908 and 95-949; Winnipeg, 95-940 and 95-981.

Statistics Canada: 1981c, Travel to Work, 1976-80, Catalogue 87-503, Table 14, Time to Work, and Table 5, Availability of Public Transportation.

Statistics Canada: 1982, The Labour Force, "Characteristics of Migrants to A1berta and B.C. 1976-1981", February.

Stub, Holger R., Editor: 1974, Status Communities in Modern Society, Alternatives to Class Analysis. (Hinsdale, I11.: The Dryden Press, Inc.).

Winnipeg Free Press: 1984, "Majority Favors Benefit Cuts, New Poll Finds," Wednesday, September 19, p. 14.

Wirth, Louis: 1938, "Urban as a Way of Life," American Journal of Sociology XLIV (JuTy), I-24. 